\title{
Impacts of the Tarlabaşı urban renewal project: (forced) eviction, dispossession and deepening poverty
}

\author{
B. Oktem Unsal \\ Department of City and Regional Planning, \\ Mimar Sinan Fine Arts University, Turkey
}

\begin{abstract}
Focusing on the Tarlabaşı urban renewal project in Istanbul, this paper examines Turkey's recent implementation of urban regeneration policies for the purpose of restructuring urban land markets. Turkey's current urban regeneration model is premised on demolishing the whole regeneration area, and rebuilding it, together with local governments and the private sector. The implementation of this model has led to the restructuring of property markets in low-income housing areas, through the regularization/legalization of tenure structures, and revalorization of the areas. It is claimed that this model solves economic and socio-spatial problems, and therefore places Istanbul in the so-called global city hierarchy. However, as the Tarlabaşı urban renewal project demonstrates, the Turkish State's regeneration model led to evictions, increasing the housing problems of the poor, deepening their poverty, and terminating the survival strategies they had developed over the years through informal economic and social networks. This paper aims to analyse the impacts this model has had, by illuminating socio-spatial aspects of the Tarlabaşı neighbourhood such as labour market dynamics, income levels, and daily life practices.

Keywords: urban renewal, gentrification, eviction, poverty.
\end{abstract}

\section{Introduction}

Following the victory of the Justice and Development Party (JDP) in the general and local elections in 2003, Turkey has been fully subscribed to an ambitious urban restructuring agenda. This agenda has targeted increasing the country's urbanization rate, modernizing cities' economic and socio-spatial structures, and 
strengthening Turkish cities' preparedness for the possibility of earthquakes. While cities are regarded as economic drivers of the global economy, Istanbul has been envisioned as a global city that will lift the Turkish economy to international levels, due to its high economic, social, geopolitical, and cultural potentials [1]. To this end, the JDP government has embarked on several megaprojects to attract fluid capital, investment, and tourists to the city. Major infrastructure projects such as new motorways, an undersea rail tunnel under the Bosphorus Strait (called Marmaray), a third bridge, a third airport, and new metro lines have been completed, and luxury businesses and housing projects, shopping and entertainment centres, have been erected all around the city. Although all local and central governments since the beginning of the 1980s have adopted these strategies with some variants, the impact of the JDP government's global city project has been larger in terms of its scale and socio-spatial outcomes.

To deliver these projects, the JDP government adopted a neo-liberal land and housing regime, and set out several legal and institutional regulations, which have reformed the built environment's actors, methods, and forms of production [2]. Urban regeneration, which has mainly targeted the informal housing areas and old historical city centres, along with former industrial estates and disused harbours, and areas where the land has a high value potential, has become the dominant urban strategy. While most of the urban regeneration projects have been realised through a central government agency, the Turkish Mass Housing Authority (TOKI), local governments, the private sector, in some cases local governments and the private sector have realised urban regeneration projects by excluding TOKI, and the Tarlabasi urban renewal project is one of them. In any case, the dominant regeneration model in Turkey is based on demolishing the whole regeneration area, and restructuring the property markets through the regularization/legalization of tenure structures, and/or revalorizing the areas. It is claimed that this model improves the housing stock of low-income housing areas in cities, addresses associated social problems, and stimulates national economic development. However, as the Tarlabaşı urban renewal project demonstrates, the Turkish State's regeneration model led to poor people being evicted, increased their housing problems, and deepened their poverty by dismantling the survival strategies they had developed over the years, through informal economic and social networks. To this extent, the state's regeneration model currently being deployed through TOKI, municipalities, and the private sector is likely to worsen, rather than improve, the housing problems of the poor. This paper analyses this model's impacts, by illuminating socio-spatial aspects of the Tarlabaş1 neighbourhood such as labour market dynamics, income levels, and daily life practices.

This paper begins by reviewing the theoretical framework that underpins the urban regeneration-state-led gentrification debate. The urban regeneration project and the various discourses espoused for/against the urban renewal project during its implementation by the different actors are discussed next. These actors include the Beyoglu Municipality, the urban regeneration company, and the media, plus the Tarlabas1 grassroots movements and citizens of the neighbourhood. Finally, 
the projects' impacts on the residents of Tarlabasi are analysed by examining the structure of the labour market, household consumption dynamics, and daily life experiences in the neighbourhood.

\section{Urban regeneration: state-led reconstruction of urban land regime}

To understand the process and impacts of urban regeneration on Istanbul's lowincome areas, it is necessary to consider the context of global and local policy developments. Since the 1980s, housing and urban policies in both developed and developing countries have focused on flagship projects targeting de-industrialised brown-field sites, run-down city centres, and disused harbour areas in order to improve the cities' images, and attract new flows of property investments, tourism, and high-end consumer spending. These projects have been promoted as necessary for a city to become a global or a creative city, and therefore a successful node in global economic flows [3, 4]. Under different labels, such as Urban Renaissance in the UK, and city competitiveness in the United States, these urban discourses urged a new approach to cities seeking to combine the improved competitiveness and job-creating capacity of the local urban economy, the reduction of sociospatial segregation, and the physical upgrading of urban facilities. Many local governments focused on improving and aestheticizing their cities by mobilizing public resources and adopting place marketing strategies, hoping to reverse outmigration and attract productive groups to the city, improve life quality in urban areas, and reduce pressures on the countryside. While urban regeneration policy has become an increasingly important field of urban policy, many governments have extended their flagship projects, which now include mega events and cultural events, and have reformulated their low-income housing policies, as part of their urban renaissance agendas.

As Wyly and Hammel [5], Goetz [6] and others argue, expanding central city real estate profit opportunities in the 1990s encouraged both private and public sector actors toward a radical transformation of both low-income housing areas and whole 'available' areas with high land value potential. These policies (the urban regeneration approach) led to the demolition of many social estates, slums, or informal settlements and brown field areas. They were replaced with middle class neighbourhoods, commercial complexes, or mega-projects. The dominant political discourse is that these urban regeneration policies have strong positive effects on cities, such as enhanced economic stability and physical renewal among others [7]. However, these policies have been criticized for the trickle-down effects of their projects, uneven development, the drain of public resources away from social policy programmes, and the displacement of low-income households through an increase in real estate values [7-9].

The causes and outcomes of the recent urban regeneration policies in lowincome housing areas have been widely discussed within the frame of the 'state led gentrification' or 'third wave gentrification' debate (Hackworth and Smith [10]). Although it is possible to find different definitions and explanations about gentrification within the related broad literature, it is generally described as 'a 
process involving a change in the population of land-users such that the new users are of a higher socio-economic status than the previous users, together with an associated change in the built environment through a reinvestment in fixed capital' [11: 258]. Although gentrification is often dated to the late 1950s as small-scale renovations, the gentrification concept today extends beyond the interests driving 'traditional gentrification' (market capital and higher income residents) into the new environment of urban renewal [12]. Smith [13: 439] claims that 'the current language of urban regeneration...bespeaks the generalisation of gentrification in the urban landscape'. It is regarded as a global urban strategy, which is about reclaiming the city for the middle classes, and is a 'consummate expression of neoliberal urbanism' [13: 441]. According to Brenner and Theodore [14: 368] 'the overarching goal of such neo-liberal urban policy experiments is to mobilise city space as an arena for market-oriented economic growth'. Hackworth and Smith [10: 441] argue that 'this has become possible because of the turn away from Keynesianism'. Although major actors leading the gentrification process were middle and upper class urbanites in the 1960s, local and international real estate developers, financial institutions, governments and public-private partnerships are the principal actors in the third wave of gentrification. The state has also been playing a much more aggressive role, by acting as a catalyst to encourage gentrification [10]. Smith [13: 441] adds that 'real estate development becomes a centrepiece of the city's productive economy, an end in itself, justified by appeals to jobs, taxes and tourism'. This is associated with the increased commodification of urban space and the empowering of private property rights [10].

The state-led gentrification literature provides a well-developed explanation for the recent urban restructuring. However, it fails to account for the governments' adoption of particular urban regeneration strategies. Lovering [15] claims that the dominant analyses of neo-liberalism suggest that the relation between the current evolution of capitalism and of urban policy is irresistible and mechanical. He adds that these political responses cannot be seen as inevitable, but rather as elements of the construction of a certain urban agenda by power elites who have certain interests in these projects (see also [16]). As Painter [17: 261] puts it, the new urban politics work 'through a complex process of negotiation, coalition, formation, indirect influence, multi-institution working and public private partnership'. So, 'gentrification as a global urban strategy', and 'gentrification as reclaiming the city for the middle classes', should be placed with the claim that central and local governments across the globe increasingly view housing development along with other property markets as an economic development strategy with gentrification being the preferred pattern of redevelopment $[5,7,13,18]$.

The next part of this paper discusses Turkey's state-led urban regeneration strategies and their effects, from the perspective of one of the most disputed urban regeneration projects in Istanbul: the Tarlabasi urban renewal project. The actors, their interests, their engagement with the project, the details of the urban regeneration model for this site and its implementation are discussed first, after which the negative gentrification effects of this regeneration model are detailed, using site residents' socio-economic structures. 


\section{Implementation of the Tarlabaşı urban renewal project}

Those responsible for effecting the spatial restructuring needed to make Istanbul a global city have targeted regions with significant historical, cultural, and natural values. Tarlabaşı is located in the Beyoğlu District, which has a rich cultural and historical inheritance. Beyoğlu, accepted as being the most western and modern face of Istanbul, became Istanbul's cultural, entertainment, and commercial centre. Its population was mostly non-Muslim in the $19^{\text {th }}$ century. It protected its multicultural and multi-ethnic qualities until the middle of the $20^{\text {th }}$ century, until the non-Muslim population left the country in the 1950s and 1960s, when Beyoğlu lost its ethnic and cultural variety, along with its commercial and business potential. While at the end of 1940s the migration from rural to urban areas and industrialisation winnowed many to the city centres, some parts of Beyoğlu also became settlement areas for the migrants. City politics made Beyoğlu a tourism and cultural centre after 1980, and triggered a rapid transformation of the district. However, Tarlabaşı could not be part of this physical and economic renewal in Beyoğlu; instead, the process of deprivation continued, along with the extension of Tarlabaşı Avenue, which was becoming a physical barrier. After Tarlabaşı Avenue was constructed, the region became disconnected from the social and economic flow in İstiklal Street and surroundings, and in 1994, the region was declared a historic site. Housing improvements were not made, due to the high cost of making repairs and needed maintenance, the complex bureaucracy, and the residents' poverty. Falling property values in Tarlabaşı and the forced Kurdish migration in the mid-1990s turned it into a low-cost housing area for escaped, undocumented, international immigrants, and various marginal groups [2]. As a result, although it could have been part of the renewal process due to its rich history and architectural houses, Tarlabaşı became a depressed region [19].

After the 2004 elections, in which Demircan was elected mayor of Beyoğlu, he stated that the first instruction of the Prime Minister of the period, and the President as of August 2014, Erdoğan, was to restore Tarlabaş1 [20]. Demircan said that the need for a new legal regulation had developed with regard to the renewal of historical city centres, due to the small sizes of the building parcels and the humble building structures in Tarlabaşı, which could not attract the desired high rents or investors [20]. On the other hand, the poverty in the region presented another obstacle to building renewal. Therefore, law No. 5366, 'Preservation by Renovation and Utilization by Revitalizing of Deteriorated Immovable Historical and Cultural Properties' was approved in 2005. Thereafter, six areas along the borders of Beyoğlu, including Tarlabaşı, were declared the renewal region. The local administration decided to conduct this urban renewal in Tarlabaşı in stages, and the renewal of 9 out of 21 city blocks in Tarlabaş1 were planned as Stage I.

Following declaration of the area as the urban renewal area, the Beyoglu Municipality anticipated the restoration or improvement of the buildings by the people living in these areas by means of the credits provided by the World Bank. In 2006, before the projects had been written, it called 444 title owners and conducted briefings about the process. The decision of immediate expropriation was reached on condition that it shall be used as needed by the municipality, in the 
same year, before these meetings come to a result. In 2007, tender was gone out for the first stage of the renewal project by the Beyoğlu Municipality and the GAP Company, known for its closeness to the government, was awarded the tender. Both the municipality and the GAP Company asserted that the renewal project had three main objectives [21]. The first was physical renewal, including renewal of that which was unhealthy and / or dangerous for the residents, due to the extremely poor condition of the entire infrastructure in the project area. The project also aimed to protect the historical urban texture, and bring housing standards up to the present. The second objective included economic recovery, investments in the tourism and service sectors, and improvements in the structural quality of the property sector, which would in turn facilitate meeting this objective. The third objective was making social progress, by integrating this isolated part of the city with the rest of the city, and ensuring that the residents of this sub-district benefitted from the changes, and also found employment here.

The Renewal Area Preliminary Project, which was prepared by the GAP Company, was not made public until it was exhibited as of 22 May 2008, for approximately two months, as part of the exhibition called 'Tarlabaşı is Sharing its Future'. Turkey's star architects had designed each of the nine blocks. The first stage of the Tarlabaşı renewal covered an area approximately 20 thousand square metres in size, and was based on the renewal of 278 buildings, of which 210 were the registered civilian architectural samples, the streets between these buildings, and the entire infrastructure. Of the renewal project, 52 per cent of the space consisted of housing areas, 12 per cent was commercial space, 17 per cent was for tourism construction, and 14 per cent consisted of office space. The approach taken did not take into consideration the authentic contours, gauges, and planning schemes of the structures, however building densities increased and new functions were suggested $[22,23]$. Once again, the decision neglected the fact that it should have been renewed with the users of these historical areas, as was emphasized in the international contracts [23].

Both the municipality and the company asserted that as a result of the renewal, those having houses and workplaces in the existing buildings would be shareholders in the new project. According to the renewal model, proprietors could get 42 per cent of their existing property value after the project was completed, or they could be paid their property's current value. The share of 42 per cent suggested to the settlers that the project was based on the current number of square meters, and this way of sharing formed the basis for the complaints that arose. In the current situation, the total project area in the nine blocks was 22 thousand square metres, and the residential area, including all storeys, was 64 thousand square metres. However, some buildings were shown to have between nine and fourteen storeys in the Preliminary Project; with this calculation, the area of usage would increase 180 thousand square meters, as a result of the renewal. Therefore, the residents' rightful share should actually be 80 thousand square metres; however, the company responsible for the project did not accept this argument.

While these meetings continued, in March 2008, those living in the renewal area established the Association for Solidarity with the Tarlabaşı Property Owners 
and Renters, to protect their rights. The Beyoğlu Municipality sent notification to the property owners in 2009, and called them for another meeting; they were told that they should sell their properties to the GAP Company, and if no consensus could be reached, the authority of 'immediate expropriation' would be used. The previous offers were renewed in these meetings; however, the property owners did not accept them. Expropriation cases were opened in the Beyoğlu Municipality Civil Court of First Instance, and the exegesis 'cannot be sold' was put on 71 buildings in title deeds at the first stage. In this court, new values were given to the buildings, and values equivalent to almost half of those suggested in the previous meetings were offered. One by one, those not selling their houses presented a case in the Administrative Court for the cancellation of the expropriation [24]. Meanwhile, the Association became involved in the case it had opened in April 2009, to suspend implementation of the project because it was counter to the international protection principle, project decisions, the science and principles of urbanism, was contrary to the public interest, and harmed the historical and cultural identity of the city. While case proceedings related to the expropriation continued, the Association applied to the European Court of Human Rights (ECHR) to suspend implementation of the project, with the justification that the project would damage the area's historical texture. The court accepted the application. Concurrently, some property owners won their cases, and were paid the deficiency payments.

In 2010, the local court rejected the case mounted by the Chamber of Architects and some of the property owners requesting suspension of the project's implementation, and the decision was appealed to a higher court. The high court cancelled the expropriation decision reached by the Beyoğlu Municipality in 2014, and cancelled the expropriations, arguing that consensus had not been reached between the parties, and the expropriations would not benefit the public. The Beyoğlu Municipality objected to the State Council's decision, and advised that the project would continue unchanged. At the end of 2014, the company began construction of the project, and said that 70 per cent of the offices had been sold. The office construction project was awarded 'The Best Urban Renewal of Europe' title in a ceremony at the $18^{\text {th }}$ International Real Estate Awards in the city of London in the UK, in September 2014. It will be completed by the end of 2015, and the residences, in 2016.

In this wearing process, during which mutual struggles continued, the property owners' legal struggles continue in the ECHR and Turkish courts. Meanwhile, the municipality used the media very well; it represented the area as being stigmatized by crime, and introduced other informalities such as gangrene and a poisoned princess. Mayor Demircan tried to legitimize the process by saying that 70 per cent of the area was empty, and the remaining residents had moved there during the previous five years, and did not have any sense of belongingness to the area [25]. However, according to a study conducted by a research group that included the author, it was confirmed that approximately 3000 people were living in the area, and 30 per cent of the residents had a property title, while the rest of the residents were tenants in the project site [26]. This study also found that living in Tarlabaş1 was important for the people, contrary to the words of the municipal authorities or 
the company executives [26]. However, all the people living in the area were displaced, together with the property rights of the majority of the property owners who were also violated. In the following section, the project's impacts on the previous area residents will be analysed, by focusing on the demographic characteristics of the population, the labour market, and the social ties that have been developed by the citizens.

\section{4 (Forced) eviction, dispossession, and deepening poverty in the Tarlabaşı urban renewal area}

The Tarlabası project area was a socio-spatially deprived and vulnerable inner city neighbourhood, whose population consisted of migrants from other Turkish cities. Kurdish people came mainly from southeast and east Anatolian regions after 1990. Others included African immigrants, Roma people, and sex workers. Those born in Istanbul accounted for 33.5 per cent, 18.8 per cent were born in East Anatolia, and 32.5 per cent were born in southeast Anatolia [26]. The majority of those born in Istanbul are less than 15 years old $(69 \%)$, and their parents came to Istanbul through forced migration in the 1990s [26]. As noted, the Tarlabaş1 urban renewal area, like many other old historical sites, has become the main settlement area for these vulnerable groups.

The Tarlabaş1 project area was a low-income housing area [26]. According to Turkun et al. [26] 2009 survey, unemployment in the research period was 16.3 per cent, above the Turkish average of 14 per cent. The people earning less than the minimum wage accounted for 40.4 per cent, which was 527 TL per month in 2009 (US\$400), and 44.9 per cent of working people were earning between 501-1000TL. The number of Tarlabasi families living below the poverty line accounted for 64.4 per cent. If we compare the household income levels in Tarlabas1 with the main trade union TURK-IS syndicate numbers, the results are even more striking; 50.2 per cent of households were under the food poverty line, while 94.9 per cent of households lived under the absolute poverty line. As members of the 'working poor', these people remained in poverty despite having jobs. The percentage of people who worked in low skilled or unskilled jobs in Tarlabası was 70.3 per cent. Their incomes did not allow them to work elsewhere in the cities, due to the travel costs.

The low-income levels and absence of other income-generating resources explains why the majority of citizens could not buy or pay high rents. Neither the Municipality nor the GAP Company had considered that the residents of the area would live there after the project had been completed. The Mayor of Beyoğlu Municipality claimed that property owners would benefit from the increase in real estate values. However, the benefits for the owners of those buildings were very limited. Only 5 per cent of the property owners have managed to buy new houses [24]. The householders who sold their houses during the first stage when threatened with expropriation or consented to the low prices for other reasons, could not purchase a new house, and moved to the lower-rent sub-districts [24]. Those that resisted sold their houses at a higher price and left the area. Some of the property owners not residing in the project area were included in the process 
[27]. Some, mostly those from the poor section, went back to their hometowns [28]. Some of those obliged to move to other sub-districts with lower rents are still working close to Tarlabaşı [29].

The municipality had not included the area tenants in the project process, but it was asserted that moving and rent assistance would be provided, and purchasing a house from Kayabaşı Social Houses within a distance of 3.5 hours to Tarlabaşı would be facilitated. One hundred and fifty families became TOKİ social house owners, and the Municipality provided rent and moving assistance. It also increased the rents in the houses it purchased, sometimes made the tenants evacuate houses in the area, stopped the water service to those not wishing to leave, and did not provide urban services [30]. Generally, property owners moved further from the area than the tenants, who moved to the streets around the project area in Tarlabaş1, or to low-rent areas close-by. The majority of the Kurdish population settled on Haciahmet Street, which shares a border with the project area [31]. According to the mukhtar of Bulbul Neighbourhood, it was said that some of the families who purchased a TOKI house in Kayabaşı wanted to rent a house around Tarlabaşı again; but it was hard for them to pay both the TOKI house instalment and rent. Transsexual individuals and sex workers moved around the project area [24]. The majority of the African population in the project area moved to Kurtuluş and Dolapdere to stay close to work [32].

The main outcomes of the Tarlabasi urban renewal project were the displacement of low-income households from the area, as the result of an increase in real estate values, harassment and (forced) eviction. It has created more poverty and social exclusion for both tenants and property owners, and dispossession for the property owners. As people in Tarlabasi strongly stressed, the negative gentrification effect of the urban regeneration model was not limited to eviction or exclusion from the labour market. They also lost their existing social networks and relationships. The low-income levels, high transportation costs, and some cultural factors limit the scope and range of families' socialization [26]. Therefore, they spent everyday life mainly in the neighbourhood, and felt that this strengthened their social ties. The locality's streets and homes are the places to socialize, especially for women and for children. As Sakızlığlu [19: 211] puts it, 'having family, townsmen, and friends in the neighbourhood is very important as that is where they feel at home and can have mutual support regarding looking after each other's kids or elderly, exchanging help regarding daily problems such as asking for social aid, borrowing/lending money, food sharing, etc. that also have economic dimensions'. It is also important that 'there are established - though always contested - cohabitation practices, norms among different marginalised groups in Tarlabasi that cannot be easily found or constructed in other neighbourhoods' [19:211]. 'For instance, it is not easy for transvestites to live in another neighbourhood, where they would probably be discriminated against and harassed. Likewise, Kurdish women with little knowledge of Turkish can speak Kurdish in Tarlabası with other Kurdish people and not feel alienated' [19: 211].

While the poor communities of the Tarlabaşı Project Area have managed to find cheap accommodation in nearby settlements, they are not secure in these places, since the local government has an urban renewal plan for all Tarlabaşı. 
Those leaving the project area and those living close to it are watching the demolitions and construction; this causes the rest of the poor and vulnerable Tarlabaşı population to have moods of rage, despair, and fear.

\section{Conclusion}

The Tarlabaşı urban renewal project is a state-led urban regeneration project. The Beyoğlu Municipality has adopted entrepreneurship, initiated and moderated the entire process. Together with the central government, by flexing the strict legal arrangements and planning processes related to the protection of these areas and the urban renewal process, they have conducted the arrangements while overseeing the transfer of all the properties belonging to the treasury to the municipality, without any authority to do so, and giving extensive powers to the local governments. The areas with high rent value at this final stage were rearranged by extending the terms and conditions of protection, and the processes and the actors of the renewal process related to the historical city centres. The area was allowed to become a slum as a result of neglect, but it held a significant place in the identity, memory, and cultural richness of the city, which is in danger of forfeiting internationally accepted protection standards. The Tarlabaşı urban renewal project has not shown respect for the rich cultural and architectural inheritance of the area [22].

The model used for the area renewal is focused on physical renewal, and it aims to renew the buildings by catching the attention of the middle and middle upper class and maximizing real estate values. Both the Beyoğlu Municipality and the company assert that the project is not just a physical renewal project, it has the social and economic tools to keep the residents in their place. However, the demolition processes have been completed and approximately 3000 people have been displaced. The renewal model process has not included the residents; the asymmetrical power relations between the actors have left their own mark on the consensus process. The Municipality decreased the participation of the property owners in the bargaining process and used the right of expropriation as a threatening element. The authoritarian attitude of the Municipality increased with the legal arrangements, the organic relations of the capital with the government, and media dominance of the capital and the state have put the people in the area in a hard struggle. Without any doubt, those living in the area have formed the weakest circle in this struggle.

The Tarlabaşı renewal project has rearranged the land regime, just as other projects have done. The focus in these arrangements is depressed areas with high real estate values. This renewal model has realized property transfers in the area, which means more poverty and social isolation for the property owners and the tenants, by maximizing the real estate values. The low rents and low selling prices in the area are important for a population having low incomes and unsafe working conditions. These real estate-based projects displace populations in city centres, and damage their working lives and conditions, social relationships, and spatial belongingness. The Tarlabaşı urban renewal project led to increases in the country's social tensions, as has happened in many other countries. The Kurdish 
population coming from their hometowns through forced migration are the poor families who form the majority of the population in the area. They have worked under too heavy conditions, and invested all their income and years of effort in these houses, only to be displaced once more, and this causes a the deepening of the tensions experienced by the Kurdish. The same tension is also valid for the transgendered and Roma people being displaced again and for the other vulnerable elements of the population. The Tarlabaşı urban renewal project neglects the concepts of equality, variability, and democracy, which should be the cornerstone of a just city, and indicates the establishment of a new regime that is authoritarian, dominant, and heedless of all the variability present in the city's lands.

\section{References}

[1] Keyder, C., Istanbul: Between the Global and the Local, Rowman and Littlefield: Maryland, 1999.

[2] Kuyucu, T. \& Unsal, O., Urban transformation as state-led property transfer: an analysis of two cases of urban renewal in Istanbul. Urban Studies, 47(7), pp. 1479-1499, 2010.

[3] Sassen, S., Global City: New York, Paris, Tokyo, Princeton University Press: New York, 1991.

[4] Florida, R., Cities and the Creative Class, Routledge, 2004.

[5] Wyly, E.K. \& Hammel, D.J., Islands of decay in seas of renewal: housing policy and the resurgence of gentrification. Housing Policy Debate, 10(4), pp. 711-771, 1999.

[6] Goetz, E.G., Where have all the towers gone? The dismantling of public housing in US cities. Journal of Urban Affairs, 33(3), pp. 267-287, 2011.

[7] Atkinson, R., Does Gentrification Help or Harm Urban Neighbourhoods? An Assessment of the Evidence-base in the Context of the New Urban Agenda. http://www.urbancentre.utoronto.ca, 2002.

[8] Davidson, M., Spoiled mixture: where does state-led 'positive' gentrification end? Urban Studies, 45(12), pp. 2385-2405, 2008.

[9] Kleinhans, R., Social implications of housing diversification in urban renewal: a review of recent literature. Journal of Housing and the Built Environment, 19, pp. 367-390, 2004.

[10] Hackworth, J. \& Smith, N., The changing state of gentrification. Tijdschrift voor Economische en Sociale Geografie, 92(4), pp. 464-477, 2011.

[11] Clark, E., The Order and Simplicity of Gentrification: A Political Challenge, Gentrification in a Global Context, eds. R. Atkinson \& G. Bridge, Routledge: London, 2005.

[12] Shaw, K., Gentrification: what it is, why it is, and what can be done about it Geography Compass, 2(5), pp. 1697-1728, 2008.

[13] Smith, N., New globalism, new urbanism: gentrification as global urban strategy. Antipode, 34, pp. 427-450, 2002.

[14] Brenner, N. \& Theodore, N., Cities and the geographies of actually existing neoliberalism. Antipode, 34(3), pp. 349-379, 2002. 
[15] Lovering, J., The relationship between urban regeneration and neoliberalism: two presumptuous theories and a research agenda. International Planning Studies, 12(4), pp. 343-366, 2007.

[16] McNeill, D. \& While, A., The New Urban Economies, Handbook of Urban Studies, ed. R. Paddison, Sage Publications: London, pp. 296-307, 2001.

[17] Painter, J., Entrepreneurs are made not born: Learning and Urban Regimes in the Production of Entrepreneurial Cities, The entrepreneurial city: geographies of politics, regime and representation, eds. T. Hall, P. Hubbard, \& P. Chichester: Wiley, pp. 259-274, 1998.

[18] Lees, L. and Ley, D., Introduction to special issue on gentrification and public policy. Urban Studies, 45(12), pp. 2379-2384, 2008.

[19] Sakızlıoglu, B., Inserting temporality into the analysis of displacement: living under the threat of displacement, Tijdschrift voor Economische en Sociale Geografie, 2014, 105(2), pp. 206-220, 2014.

[20] Demircan A.M, Interviewed by Pınar Öğünç, Radikal, 'Tarlabaşı'nda Cumbalı Okazyon Günleri Başladı', 25.08.2007, http://www.radikal.com.tr.

[21] Tarlabası 360, Tarlabaşı Urban Renewal Project Web Site, Istanbul, http://www.tarlabasi360.com/en.

[22] Tonbul, Z., Politics of renovation: urban regeneration the case of Tarlabaşı, Istanbul, Architecture and the Political, Fourth International Symposium on Architectural Theory, November 10-12, 2011, Beirut, Lebanon.

[23] The Chamber of Architects, Tarlabaşı Urban Renewal Project Case File, The Chamber of Architects Web Site, www.mimarist.org, 2008.

[24] Person, E.A. Personal communication, 25 October 2012, Secretary of Association for Solidarity with Tarlabaş1 Property Owners and Renters, Istanbul, Turkey.

[25] Radikal Gazetesi, Tarlabaşından Şanzelize Olur Mu?Radikal Gazetesi Web Site, http://insaat.diyalog.com, 10.08.2011.

[26] Turkun, A., Sen, B., Oktem Unsal, B. and Aslan, S., Istanbul'da Eski Kent Merkezleri ve Gecekondu Mahallelerinde Kentsel Donusum ve SosyoMekansal Değisim., TUBITAK Project Number 108K134. TUBITAK: Ankara, 2010.

[27] Person S. Personal communication, 15 October 2013, renters, Istanbul, Turkey.

[28] Person A.G. Personal communication, 10 October 2014, Head of Association for Solidarity with Tarlabaşı Property Owners and Renters, Istanbul, Turkey.

[29] Person M.A. Personal communication, 12 October 2013, Property Owner, Istanbul, Turkey.

[30] Bianet, Tarlabaşından Gitmeyene Su Yok, Bianet, Web Site, 14 February 2013, www.bianet.org.

[31] Person M.Ç. Personal communication, 12 October 2013, Mukhtar of Bulbul Neighbourhood, Istanbul, Turkey.

[32] Person Y.K. Personal communication, 22 October 2013, Property Owner, Istanbul, Turkey. 